\title{
Conversion of Palm Oil Mill Effluent on Biogas Production with Consortium Bacteria
}

\author{
Nyimas Ulfatry Utami ${ }^{\#}$, Muhammad Said ${ }^{\#, *}$, Muhammad Faizal ${ }^{\#}$, Leily Nurul Komariah ${ }^{\#}$ \\ ${ }^{\#}$ Chemical Engineering Department, Faculty of Engineering, Sriwijaya University, Palembang, 30139, Indonesia \\ E-mail: *saidm_19@yahoo.com
}

\begin{abstract}
Palm Oil Mill Effluent (POME) is a liquid waste that has a high organic content and it can be fermented using bacteria to produce biogas. POME is non-toxic but the high organic contents can disturb the ecosystems and cause the environmental pollution in the water body. POME contains microorganisms that have the potential to hydrolyze oils, celluloses, and protein. Potential bacteria for degradation of POME can be obtained by isolating the waste itself (indigenous bacteria). Indigenous bacteria that have been isolated from POME, namely: Stenotrophomonas rhizopila strain E-P10 (KP 1.2) and Bacillus toyonensis strain BCT-7112 (KAN 1) are used as consortium bacteria in the process of waste degradation. The research sequence consists of rejuvenation of bacteria, preparation of medium mineral, starter and bacterial inoculum. The research aims to degrade the substrates from POME using a consortium and indigenous bacteria to produce biogas. The substrate degradation process is carried out in a bioreactor with degradation time 0, 20, 21-22, 23-26, 27-30, 31-34 and 35-38 days. Bacterial population growth was calculated using a haemacytometer. The highest population of the consortium and indigenous bacteria were found at $7.94 \times 10^{7} \mathrm{mg} / \mathrm{mL}^{\mathrm{and}} 7.23 \times 10^{7}$ $\mathrm{mg} / \mathrm{mL}$. The biogas contents were analyzed using the Gas Chromatography (GC) with units of \% mole. The highest production of biogas contains $68.6 \%$ mole methane gas $\left(\mathrm{CH}_{4}\right)$ and $21.7 \%$ mole carbon dioxide gas $\left(\mathrm{CO}_{2}\right)$ with the consortium bacteria. While using the KAN 1 bacteria, the highest production of biogas contains $64.0 \%$ mole methane gas $\left(\mathrm{CH}_{4}\right)$ and $22.0 \%$ mole carbon dioxide gas $\left(\mathrm{CO}_{2}\right)$.
\end{abstract}

Keywords - palm oil mill effluent; consortium bacteria; biogas.

\section{INTRODUCTION}

The growth of the palm oil industry in Indonesia continues to increase. Crude Palm Oil (CPO) into one of a commodity that has the highest for consumption and produced in the world. CPO is one of the flagships of Indonesian agricultural products both as raw materials of vegetable oil and export commodities. To achieve maximum profit, CPO producers need to produce efficient production. Indonesia became one of the largest manufacturers and exporters in the world with production reaching 34.47 million tons in 2017. This value has increased by $9.46 \%$ compared to 2016. If it is seen from its contribution, $57.24 \%$ is derived from private plantations, $36.76 \%$ from people's plantations and $6.00 \%$ are derived from government-owned plantations. The CPO market prospects are still very bright because of the high demand of the world. It is characterized by the vast area of palm oil plants that is overgrowing in Indonesia. Increased CPO production is supported by the total area of growing oil palm plantations, which is $12,298,450$ ha in 2017 from 11,201,465 ha in 2016. Indonesia's palm oil production is largely exported to foreign countries and the rest is marketed domestically. The increase in CPO production is also caused by rising demand in local markets, especially the vegetable oil industry and other food industries. Besides, increased CPO production is driven by the growing biodiesel industry that uses CPO as the main raw material for the past few years. Indonesia's palm oil exports span five continents of Asia, Africa, Australia, America, and Europe with a major share in Asia [1].

Along with the increased production of the palm oil industry, the result is an increase in the amount of CPO waste, which is also referred to as the Palm Oil Mill Effluent (POME), also referred to as liquid waste [2]. It has organic content that can be fermented with bacteria to produce biogas. POME containing many fatty acids, protein, carbohydrates, phosphate, potassium, magnesium, nitrogen and calcium, so it can be processed as a fertilizer. Every ton of palm oil fresh fruit bunch will raise about $0.7 \mathrm{~m}^{3}$ to $1 \mathrm{~m}^{3}$ of POME waste. POME that comes out of the treatment process having a high temperature, between $60{ }^{\circ} \mathrm{C}$ to $80{ }^{\circ} \mathrm{C}$, with the level of acidity $(\mathrm{pH})$ around 3.3 to 4.6 [3]. POME is non-toxic, but the high organic content causes the value of Chemical Oxygen Demand (COD), Biological Oxygen Demand (BOD) and Total Suspended Solid (TSS) which is quite high, so it can interfere with ecosystem [3]-[4] and the 
most problematic potential of environmental pollution [5]. The compositions of the POME can be measured by standard methods in accordance with the ASTM standards (ASTM 2000) among others are solids volume fraction $(\phi)$ of $0.177 \pm 0.003 \mathrm{v} / \mathrm{v}$, COD of $44,800 \pm 3500 \mathrm{mg} / \mathrm{L}$, BOD of $21950 \pm 1000 \mathrm{mg} / \mathrm{L}$, TSS of $20950 \pm 1500 \mathrm{mg} / \mathrm{L}$, total solids (TS) of 48,680 $\pm 3,400 \mathrm{mg} / \mathrm{L}$, volatile solids (VS) of $993 \pm$ $60 \mathrm{mg} / \mathrm{L}$, oil and grease of $653 \pm 0.3 \mathrm{mg} / \mathrm{L}$, temperature of $65 \pm 2.8^{\circ} \mathrm{C}$ and $\mathrm{pH}$ of $4.64 \pm 0.3$ [6].

The open pool system is one of the most widely used POME sewage treatment today, in which there is anaerobic and aerobic decomposition. The anaerobic ponding system is one method that is often used and not environmentally friendly. Disadvantages of this conventional system, namely requiring extensive land, long retention time, releasing harmful gases (such as $\mathrm{CH}_{4}$ and $\mathrm{CO}_{2}$ ) and the accumulation of mud [7], [8]. Also, because a large volume of gas produced by the greenhouse was not completely captured, but out into the atmosphere. The other methods of POME treatment among others are chemical treatment (example: floatation and adsorption; coagulation and flocculation), aerobic digestion (example: rotating biological contactor and activated sludge reactor), anaerobic digestion high-rate closed system (example: continuous stirred tank reactor, anaerobic fluidized bed reactor, and up-flow anaerobic sludge blanket reactor), anaerobic ponding system (example: open lagoon system) and physical treatment (example: centrifugation and sedimentation) [9].

Many disadvantages of POME processing with a conventional system, it is necessary to the development of other methods where POME can be redeveloped by anaerobic bacteria through the process of anaerobic degradation in the environment with less oxygen and change it from the form of suspended into dissolved and biogas. Biogas contains some of the largest components such as methane, carbon dioxide and small amounts of other gases. The process of anaerobic degradation can take place in varying temperatures, depending on the type of bacteria used and require nutrient intake for the bacteria used [10], [11]. In Indonesia, many palm oil mill factories use an open pond system to process POME, with consideration of economy and ease of operation. In the open system management process, POME undergoes several processing steps by going through a series of ponds. The naming and function of the pond may vary between factories and others, but in general, there are four types of ponds, such as fat pit, cooling pond, anaerobic pond, and aerobic pond. The residual oil and grease in POME will be collected in a fat pit. Oil is the main product of the factory, so the factory operator will quote oil from the fat pit and re-flowing to the CPO processing unit. The cooling pool serves to lower the POME temperature to achieve optimal conditions for the parsing process of organic substances in anaerobic ponds. After processing is completed in all four ponds and quality standards are met, then the liquid waste can be streamed to the river or used as fertilizer. Despite the economical pool system, this system requires a wider area, time-consuming, and remove the methane directly into the atmosphere from the breakdown of organic substances occurring in the anaerobic pool. The release of methane from the POME processing system contributes up to $70 \%$ of total greenhouse gas emissions in the overall CPO production process. The details contents of biogas from both estimates and actual yield from biomass among others are methane $\left(\mathrm{CH}_{4}\right)$ of 55-75\%, carbon dioxide $\left(\mathrm{CO}_{2}\right)$ of $30-45 \%$, hydrogen sulfide $\left(\mathrm{H}_{2} \mathrm{~S}\right)$ of $1-2 \%$, nitrogen $\left(\mathrm{N}_{2}\right)$ of $<3 \%$, hydrogen $\left(\mathrm{H}_{2}\right)$ of $0-10 \%$ and oxygen $\left(\mathrm{O}_{2}\right)$ of $<1 \%$ [12].

Biogas is physically a liquid gas characteristic. Therefore, the process requires a room in the condition of the village or closed to be stable. In principle, biogas is formed through several processes that take place in various spaces or without oxygen. The processes that take place in various in this closed house also give an ecological advantage because it does not cause the smell that spreads. In principle, the technology of biogas is a technology that utilizes the process of fermentation (decay) of organic waste anaerobic (without air) by the methanogen bacteria resulting in methane. Biogas has a mass of about $20 \%$ lighter than air and an ignition temperature between $650-750{ }^{\circ} \mathrm{C}$. It is colorless and odorless gas when burned will result in a clear blue flame like Liquefied Petroleum Gas (LPG). The heat value of methane gas is $20 \mathrm{MJ} / \mathrm{Nm}^{3}$ with a combustion efficiency of $60 \%$ in conventional biogas stoves. The biogas volume is usually written in normal cubic meters $\left(\mathrm{Nm}^{3}\right)$, the volume of gas at $0{ }^{\circ} \mathrm{C}$ and pressure in atmospheric.

The raw material in the form of cellulose is easier to digest by anaerobic bacteria. If the raw material contains a lot of wood or lignin, for example, a straw that contains many wood substances so it is very difficult to digest. The raw material will float on the liquid surface and form the crust so that it will block the rate of biogas production [3]. Naturally, potential bacteria as a decomposer can be obtained by isolating the waste itself (indigenous bacteria) and then culture purely in a laboratory in vitro. The utilization of potential consortium bacteria will be reproduced for further use as a starter in sewage treatment. The transformation is carried out by microorganisms, particularly the grading bacteria to produce enzymes through the metabolic process. Optimization of environmental conditions is done so that microbial metabolic activity can take place well. When bacteria consortium is used as an inoculum, the process of anaerobic degradation occurs, including the process of hydrolysis (conversion process: proteins to peptides and amino acid; carbohydrates to monosaccharides; lipids to its lower fatty acid and glycerol), acidogenesis process (conversion process: amino acids to fatty acids and acetate; sugar to lower metabolites), acetogenesis process (conversion process: alcohol or fatty acid is converted to acetate or hydrogen) and methanogenesis process (conversion process: hydrogen and carbon dioxide to methane; acetate to methane and carbon dioxide). The stages of the process on the anaerobic processing are closely related to each other [13]. Raw materials are the main factors that determine the quality of biogas produced. Some types of raw materials often used include waste of livestock impurities, agricultural waste, industrial waste, waste of organic waste the waste of water. In principle, the stages in the biogas formation process have several parameters of materials and factors that must be considered well. These factors include a substrate of organic matter, degrees of acidity $(\mathrm{pH}), \mathrm{C} / \mathrm{N}$ ratio, temperature, replenishment rate, toxic substances, stirring, starter and 
retention time. The biogas formation process is not separated from the performance of microorganisms. Microorganisms that are methanogenic bacteria help the fermentation process to the formation of biogas. These bacteria work to remodel organic matter and convert it into methane gas.

Characteristic of methanogenic bacteria can live in an anaerobic environment, generally, these bacteria are present in rumen impurities and human impurities. Methanogenic bacteria can be obtained from the dung of livestock itself or isolated from the rumen of cows as a starter. In addition to being contained in solid dirt, methanogenic bacteria are also contained in the form of liquid and mixed organic matter. Methanogenic or methanogen bacteria are bacteria found in organic ingredients and produce methane and other gases with the entire process of its life chain in anaerobic conditions. As living organisms, there is a likelihood of liking certain conditions and sensitive microclimate in the digester. There are many species of methanogen and its variety of properties. Biogas production is carried out in a reactor/digester. The principle of building digester is to create an airtight space (anaerobic) that blends with the channels or inputs and channels or the production (output). The insertion body serves to homogenize the raw material of liquid and solid waste. If solid waste in an agglomerate condition, then it is necessary stirring so that it is easier to get into the digester and the process of reshuffle easier. The shelter aims to accommodate sludge the result of the reshuffle of organic matter from the digester that has been decked the organics, but it will increase the nutrients - the reshuffle reaction of organic matter as follows.

$\begin{array}{lccr} & \text { Microorganism } & & \\ \begin{array}{l}\text { Organic wastes } \\ \text { sludge }\end{array} & \text { anaerobic } & \mathrm{CO}_{2}+\mathrm{CH}_{4}+\left(\mathrm{NH}_{3}+\mathrm{H}_{2} \mathrm{~S}+\mathrm{CO}\right)+ \\ & & \text { dominant } & \text { slight }\end{array}$

Both aerobic and anaerobic decomposition can effectively reduce the content of organic substances in liquid waste. Anaerobic processes occur in a state without oxygen, whereas aerobic processes occur when there is oxygen. POME application can be utilized as energy using anaerobic processes. The main reason to choose an anaerobic process is its ability to produce biogas well. The aerobic process does not convert organically into methane, generating more mud, and processing waste more thoroughly. Conversely, the anaerobic process produces methane and residual liquid waste that is rich in nutrients such as phosphorus and nitrogen.

Many POME processing studies have been completed, biogas is produced from a mixture of POME and the fermented mud produces methane $\left(\mathrm{CH}_{4}\right)$ of $59.15 \%$ or 0.28 $\mathrm{m}^{3}$ at a temperature of $55{ }^{\circ} \mathrm{C}$ [14]. Biogas production to increase the methane $\left(\mathrm{CH}_{4}\right)$ content from POME processing uses the System Shear-Loop Anaerobic Contact Stabilization (SLACS) reactor type with two-level processing resulting in $256 \mathrm{mLg}^{-1} \mathrm{VS}$ or $32 \%$ compared to one processing [15]. Meanwhile, the production of biogas from POME and Empty Fruit Bunch (EFB) produces methane $\left(\mathrm{CH}_{4}\right)$ of 320 $\mathrm{mL} \mathrm{CH}_{4} / \mathrm{gVS}$ with a biodegradable capability of $63 \%$ to $70 \%$ [16]. Other research from POME processing by elaborating substrates using Escherichia coli bacteria to produce biohydrogen, where the culture was incubated at $37{ }^{\circ} \mathrm{C}$ for
24 hours with mild stirring resulting in carbohydrate conversion into hydrogen and Maximum Hydrogen Yield (MHY) of $0.66 \mathrm{~mol} \mathrm{H}_{2} /$ total monomeric sugars and productivity of $3,551 \mu \mathrm{mol} / 10^{10} \mathrm{cfu}$ [17]. In addition to using bacteria, POME's processing studies have been conducted using insulating mushrooms that were previously examined by the Indian oil processing industry. One of the best types of insulating mushrooms acquired is Emericella nidulans NFCCI 3643 which can lower COD of $80.28 \%$, BOD of $88.23 \%$ and oil/fat content of $87.34 \%$ thereby optimizing the environmental condition of POME impact [18].

POME contains many microorganisms that have the potential to hydrolyze fats and oils. One way to acquire the potential bacteria in degraded liquid waste while using POME as a nutritional source is to isolate with specific media in its ability to test. Pseudomonas species, Staphylococcus aureus, and Bacillus species are some examples of bacteria that produce lipase [19]. The purple phototrophic bacteria can be used for the upgrading of biogas from the treatment of piggery wastewater. This study evaluated in a gas-tight photobioreactor. The piggery wastewater was diluted four times and supported with total organic carbon of $78 \%$, total nitrogen removals of $13 \%$ and the methane concentrations of $90.8 \%$. The purple phototrophic bacteria supported concentrations of methane in the upgraded biogas of $93.3 \%$ and $73.6 \%$ [20]. Biogas production can be produced from a mixture of POME and activated sludge with some various concentrations of $10 \%$, $20 \%$ and $30 \%$ in the truncated pyramid digester for 30 days. During the fermentation process in the fed-batch system, there is a significant influence on biogas production. Each variation of the composition of the mixture results in a different biogas rate and the result is the highest quantity from the methane $\left(\mathrm{CH}_{4}\right)$ of $24.96 \%$ mole at a ratio of $10: 90$ and the lowest quantity is $9.48 \%$ mole in ratio 30:70 [21]. The production of methane and hydrogen from palm oil mill effluent can be produced from accelerated two-stage bioprocess using continuous stirred tank reactor (CSTR) and mesophilic microbial electrolysis cell. The reactor of CSTR was operated at $80 \mathrm{rpm}, \mathrm{pH}$ of 5.5, hydraulic retention times of two days, organic loading rate of $60 \mathrm{gr} \mathrm{COD} / \mathrm{L}$ days and temperature of $55{ }^{\circ} \mathrm{C}$ with a hydrogen yield of $205 \mathrm{~mL} \mathrm{H}$ gr/COD along with butyric, acetic, lactic and propionic acid as by-products. This study has resulted in a methane yield of $290 \mathrm{~mL} \mathrm{CH}_{4} \mathrm{gr} / \mathrm{COD}$ and a production rate of $2,700 \mathrm{~mL}$ $\mathrm{CH}_{4} / \mathrm{L}$ with hydraulic retention times of 8 days [22].

Production of biogas from anaerobic digestion can evaluate with life cycle analysis using the ReCipe 2016 method and SimaPro 8.5 software. Global warming, water consumption and land-use change have significant contributions. It can be founded that the total characterization factor for human health damage by water consumption and global warming ranges from $2.49 \times 10^{-8}$ to $3.36 \times 10^{-3}$ DALY per $\mathrm{m}^{3}$ of consumption and $1.45 \times 10^{-5}$ to $1.42 \times 10^{-3}$ DALY per $\mathrm{kg}$ of emission, respectively. It was concluded that biogas derived from waste is a promising technology that can be used to meet the national goals in the process of forming sustainable renewable energy [23]. An initial study was made to produce biohydrogen and biomethane from palm oil mill effluent using a two-stage up- 
flow anaerobic sludge fixed-film (UASFF) bioreactor with the composition of $100 \%$ molasses and POME of $10 \%$ increments until it reached $100 \%$ after 59 days. During this processing period, the hydraulic retention time and temperature were controlled to optimize the condition to produce biogas. The production of methane and hydrogen were fluctuated between $53-70 \%$ and $90-95 \%$, with the POME percentage being increased from $70 \%$ to $100 \%$. The raw POME was used by $100 \%$ with produce total COD removal of $83.70 \%$, average gas production rates of $9.60 \mathrm{~L}$ $\mathrm{CH}_{4} \mathrm{~d}^{-1}\left(94.08 \% \mathrm{CH}_{4}\right)$ and $5.29 \mathrm{~L} \mathrm{H}_{2} \mathrm{~d}^{-1}\left(57.11 \% \mathrm{H}_{2}\right)$ [24].

The purpose of this research is to convert POME into biogas using a consortium of indigenous bacteria, namely Stenotrophomonas Rhizopila strain E-P10 (KP 1.2) and Bacillus toyonensis strain BCT-7112 (KAN 1) that have been isolated anaerobic previously. The results will be compared with biogas from indigenous bacteria of KAN 1. The bacteria of KP 1.2 is a bacterium that has anaerobic properties, lipolytic and has a gas content. While bacteria of KAN 1 is a bacterium that has anaerobic properties, proteolytic and cellulolytic and it has a gas content. The condition for biogas production is the anaerobic system.

\section{MATERIALS AND METHOD}

\section{A. Bioreactor Design}

To produce biogas, it is necessary for a reactor/digester. This study uses a cylinder-shaped bioreactor with a volume of 10 liters, the top is covered with a rubber stopper and fitted a gas faucet to open and close the gas flow to the Tedlar bag. Between a gas faucet and a Tedlar bag is connected to the hose that can be opened if the Tedlar bag is replaced. The lid is lined with plaster to prevent air from entering. The digester has a role in reducing methane gas emissions $\left(\mathrm{CH}_{4}\right)$ resulting from the decomposition of organic matter manufactured from the agriculture or livestock sector. With the use of digester, organic waste is fermented into methane gas (biogas). Choosing a digester should pay attention to several factors, such as size, model, material and resistance to temperature, weather or earthquake.

\section{B. Rejuvenation of Bacteria, Preparation of Mineral Medium (MM) and Starter}

Palm oil waste (POME) intake in PT Agro Indralaya Mandiri, regency of Ogan Ilir, district of North Inderalaya, South Sumatera. The liquid waste will then be mixed with mineral medium, bacterial inoculum, and starter. The agar medium was made by dissolving $20 \mathrm{~g}$ of agar into the Aquadest $100 \mathrm{~mL}$. The solution was heated and sterilized in an autoclave for 1 hour. Then it was taken as much as $7 \mathrm{~mL}$ into each of the 6 pieces of sterile reaction tubes and tilted for 15 minutes. Bacterial culture of Stenotrophomonas Rhizopila strain E-P10 (KP 1.2) and Bacillus toyonensis strain BCT-7112 (KAN 1) is inoculated to each of the 3 reaction tubes using a sterile ose needle in a zigzag way.

The chemicals used to make a mineral medium as much as $1 \mathrm{~L}$ is $\mathrm{MgSO}_{4} .7 \mathrm{H}_{2} \mathrm{O}$ of $0.2 \mathrm{~g}, \mathrm{~K}_{2} \mathrm{HPO}_{4}$ of $4.5 \mathrm{~g}, \mathrm{CaCl}_{2}$ of $0.1 \mathrm{~g}, \mathrm{NaCl}$ of $0.1 \mathrm{~g}, \mathrm{FeCl}_{3}$ of $0.02 \mathrm{~g}$, $\left(\mathrm{NH}_{4}\right)_{2} \mathrm{SO}_{4}$ of $0.2 \mathrm{~g}$, beef extract of $3 \mathrm{~g}$, yeast extract of $5 \mathrm{~g}$ and sterile aquadest of $1 \mathrm{~L}$. The solution was heated and sterilized in the autoclave for 1 hour at $121{ }^{\circ} \mathrm{C}$ and 15 psi. The medium of nutrient broth was made by dissolving nutrient broth of $6 \mathrm{~g}$ into aquadest of $750 \mathrm{~mL}$ in an Erlenmeyer. It was heated and sterilized in the autoclave for 1 hour. The oil substrate preparation for consortium bacteria is POME $6 \mathrm{~L}$ waste, a mineral medium of $2 \mathrm{~L}$ and added vegetable oil of $62 \mathrm{~mL}$. The oil substrate preparation for KAN 1 bacteria is POME 6 $\mathrm{L}$ waste, a mineral medium of $2 \mathrm{~L}$, skim milk of $6.2 \mathrm{~g}$ and carboxymethylcellulose (CMC) of $6.2 \mathrm{~g}$.

\section{Substrate Degradation Process of POME}

The manufacture of $2 \mathrm{~L}$ starter consisting of the bacteria inoculum KP 1.2 of $250 \mathrm{~mL}$, the bacteria inoculum KAN 1 of $250 \mathrm{~mL}$, a medium mineral of $1,100 \mathrm{~mL}$ and POME waste of $400 \mathrm{~mL}$. It was then added to the liquid substrate of $8 \mathrm{~L}$ and incorporated into the consortium bioreactors. In the same way, $2 \mathrm{~L}$ of starter consisting of the bacteria inoculum KAN 1 of $250 \mathrm{~mL}$, a medium mineral of $1,100 \mathrm{~mL}$ and POME waste of $400 \mathrm{~mL}$. It was then added to the liquid substrate of $8 \mathrm{~L}$ and incorporated into the KAN 1 bioreactors. The bioreactors were operated in anaerobic conditions. This degradation process lasts for 38 days. Measurement of bacterial cell count carried out at the time of forming biogas that is accommodated in Tedlar bag. The liquid was taken to measure the amount of bacterial population. The amount of bacterial populations formed is observed using a haemacytometer. It is then observed using a microscope and several bacteria can be calculated manually in cubical spaces. The sample of the substrate of $40 \mathrm{~mL}$ was taken every 3 days to analyze the $\mathrm{pH}$ parameter. The value of $\mathrm{pH}$ and bacterial population were measured for the analyze data.

\section{Determination of Bacterial Population and Biogas}

The sample of the liquid substrate from consortium and KAN 1 bacterial of each $50 \mathrm{~mL}$ was taken in a glass tube with a cap. Prepare 9 pieces of reaction tubes that were filled with aquadest of $9 \mathrm{~mL}$ for each tube. It was covered with cotton and paper. Petri dish of 3 pieces was covered with papers. The reaction tubes, petri dish and agar nutrient were sterilized in the autoclave for 1 hour. The reaction tubes were filled with the liquid substrate sample of $1 \mathrm{~mL}$ using a micropipette and these were diluted to $10^{-1}$ to $10^{-9}$. The samples and media of agar nutrients were filled in the petri dish and these were left until solidification. These were kept in the incubator with an upside position for 2 days. The bacterial population was calculated with a microscope or direct method. Biogas was formed from the degradation process was kept in a Tedlar bag. The composition of biogas was analyzed using gas chromatography (GC).

\section{RESULTS AND DISCUSSION}

\section{A. Bacterial Population Growth $(X)$}

Growth can be defined as the increase of numbers or the volume and size of cells. In bacteria, growth is an increase in the number and size of cells. The growth of bacterial cells will usually follow a certain pattern of growth to form a sigmoid growth curve. These curves describe the state of the bacteria in the culture at any given time and see if the bacteria will continue to grow and reach its optimum point over time so that the process increases or decreases. Between each phase, there is a transition period where time can pass 
before all the cells enter a new phase. Bacterial growth time is the time needed for cells to divide, depending on the type of bacteria and the conditions of growth, nutrients and the type of substrate that is suitable for the degradation of bacteria. Relationship time degradation between population growth the consortium and KAN 1 bacterial can be seen in Fig. 1.

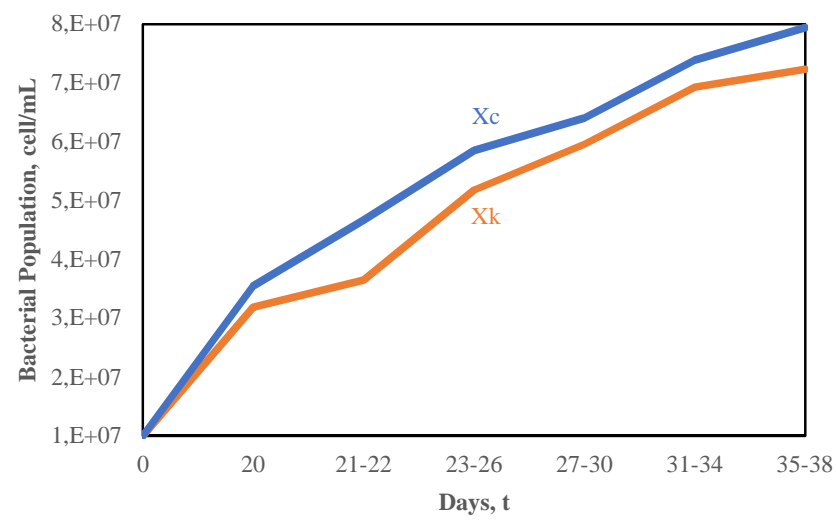

Fig. 1 Consortium (Xc) and KAN 1 (Xk) bacterial population growth along degradation time

As shown in Fig. 1, consortium and KAN1 bacteria require a phase adjustment with a new environment. The number of bacterial populations formed by the consortium and KAN 1 bacteria are increasing and requires sufficient time to develop properly. On the $20^{\text {th }}$ day, a population of consortium (Xc) and KAN $1(\mathrm{Xk})$ bacterial formed amounted to $3.55 \times 10^{7} \mathrm{mg} / \mathrm{mL}$ and $3.19 \times 10^{7} \mathrm{mg} / \mathrm{mL}$. The growth of the consortium and KAN 1 bacterial population continues to increase linearly to $7.94 \times 10^{7} \mathrm{mg} / \mathrm{mL}$ and 7.23 x $10^{7} \mathrm{mg} / \mathrm{mL}$ on the $35-38^{\text {th }}$ day. The number of bacterial populations from the consortium bacteria is greater than the KAN 1 bacteria. If the consortium and KAN 1 bacterial growth conditions are well controlled, the growth will be better. This can occur depending on the composition of the media, nutrients, $\mathrm{pH}$, temperature, aeration, several cells in the initial inoculum and the physiological properties of the bacteria in the previous media so that degradation of the bacterial against the substrate become optimal.

\section{B. Production of Methane Gas $\left(\mathrm{CH}_{4}\right)$}

When the methane gas is formed from the substrate degradation process at each time interval will be analyzed using gas chromatography (GC). Methane gas is the first largest composition of biogas. If biogas has a high methane gas content, it has a high heating value. Therefore, the amount of methane gas that is formed depends on the number of moles of gas that can be formed per one mole of the degraded substrate over time. As shown in Fig. 2.

As shown in Fig. 2 that the consortium and KAN 1 bacteria need an optimal time to produce biomass so that it can produce methane gas and other gases. It takes approximately 20 days to produce $37.5 \%$ mole and $33.0 \%$ mole of methane gas from the consortium and KAN 1 bacterial. With the increasing growth of the consortium and KAN 1 bacterial population, the gas content produced will also increase. The content of methane gas is formed as a result of the optimal degradation by the consortium and KAN 1 bacterial. On the day $35-38$, it was formed $68.6 \%$ mole and $64.0 \%$ mole of methane gas from the consortium and KAN 1 bacterial. The amount of methane gas produced from the consortium bacteria is greater than the KAN 1 bacteria. The Consortium and KAN 1 bacteria have an important influence and role in each process of substrate degradation to produce excellent biogas formation. Providing adequate nutrients and following bacterial conditions can affect the growth of bacterial populations so that the number of bacterial populations becomes optimal.

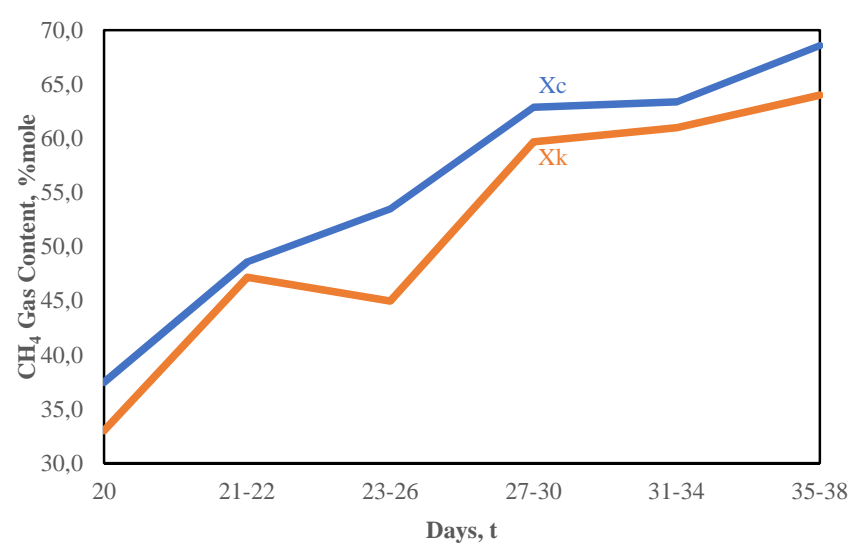

Fig. 2 Relationship time degradation with the production of methane gas $\left(\mathrm{CH}_{4}\right)$

\section{Production of Carbon dioxide Gas $\left(\mathrm{CO}_{2}\right)$}

Carbon dioxide gas is the second-largest gas component after methane gas in biogas production. This gas is less profitable because it causes the heat efficiency produced is still low so that the biogas flame is still not optimal. Therefore, the carbon dioxide gas level that should be maintained is $30-45 \%$ [12]. For that, $\mathrm{CO}_{2}$ gas in biogas needs to be eliminated because the gas can reduce the heating value of biogas combustion. To reduce the levels of $\mathrm{CO}_{2}$ contained in biogas, several methods can be used, such as chemical absorption, membrane separation, water scrubbing, cryogenic upgrading, and vacuum or pressure swing adsorption (PSA/VSA) [25]. As shown in Fig. 3.

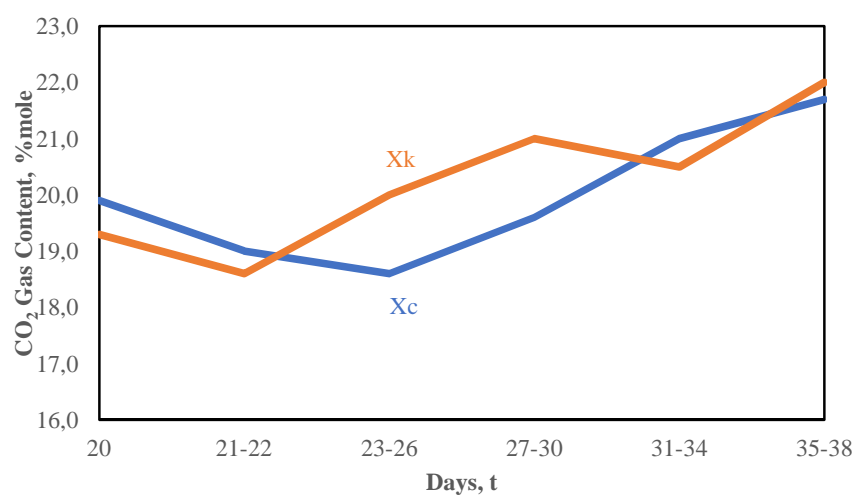

Fig. 3 Relationship time degradation with the production of carbon dioxide gas $\left(\mathrm{CO}_{2}\right)$

From Fig. 3 can be seen that the carbon dioxide gas resulting from the degradation of POME by the consortium and KAN 1 bacteria also increased. It was needed 20 days to produce carbon dioxide gas of $19.9 \%$ mole $19.3 \%$ mole from the consortium and KAN 1 bacterial. The highest production 
of carbon dioxide gas is $21.7 \%$ mole and $22.0 \%$ mole from the consortium and KAN 1 bacterial on the $35-38^{\text {th }}$ day.

\section{Production of Oxygen Gas $\left(\mathrm{O}_{2}\right)$}

The oxygen gas content in biogas is not required because this process uses anaerobic fermentation that does not require oxygen. The greater the oxygen gas content in the degradation process, it will inhibit the production of methane gas by bacteria. Therefore, the oxygen gas level that should be maintained is < $1 \%$ [12]. In this study, the oxygen gas produced can be seen in Fig. 4 .

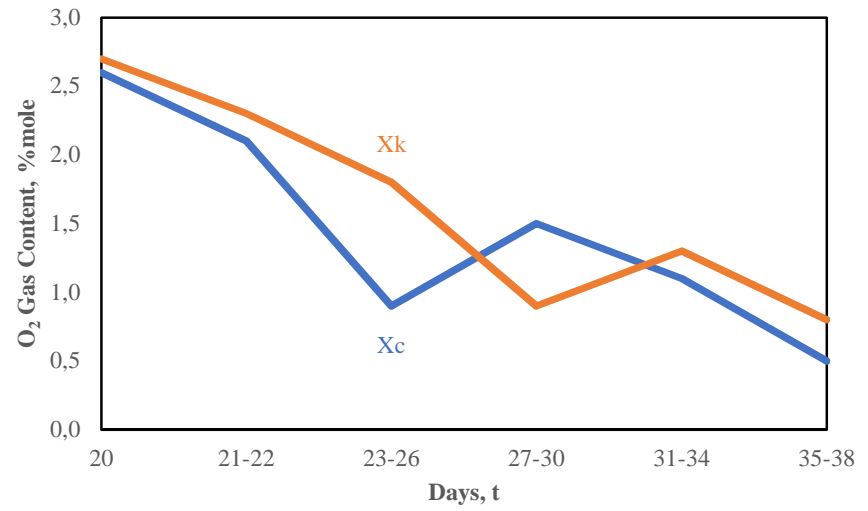

Fig. 4 Relationship time degradation with the production of oxygen gas $\left(\mathrm{O}_{2}\right)$

As shown in Fig. 4, in the process of the $20^{\text {th }}$-day biogas formation, oxygen gas produced amounted to $2.6 \%$ mole and $2.7 \%$ mole from the consortium and KAN 1 bacterial. This value is quite large, but as the time of the bacterial degradation is produced the value of the oxygen gas is increasingly smaller of $0.5 \%$ mole and $0.8 \%$ mole from the consortium and KAN 1 bacterial on the $35-38^{\text {th }}$ day.

\section{E. Production of Nitrogen Gas $\left(N_{2}\right)$}

Nitrogen gas is one of the impurities that are found in the biogas content. Methane gas is a combustible organic component, while carbon dioxide and nitrogen gases are inert gases that do not react to combustion processes. The nitrogen gas content produced in this study can be seen in Fig. 5.

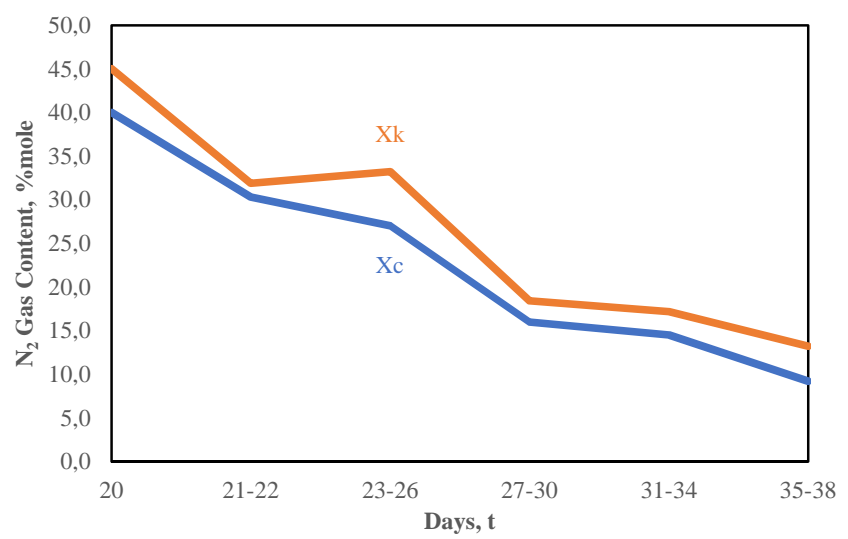

Fig. 5 Relationship time degradation with the production of nitrogen gas $\left(\mathrm{N}_{2}\right)$

As shown in Fig. 5, the nitrogen gas produced is $40.0 \%$ mole and $45.0 \%$ mole from the consortium and KAN 1 bacterial on the $20^{\text {th }}$ day. This value is quite large, but as the time of the bacterial degradation is produced the value of the lower nitrogen gas content, which is $9.2 \%$ mole and $13.2 \%$ mole from the consortium and KAN 1 bacterial on the 35 $38^{\text {th }}$ day.

\section{F. Analysis of $p H$}

The high degree of acidity $(\mathrm{pH})$ is associated with the performance of microorganisms in assisting the fermentation process. Microorganisms will be effective in the $\mathrm{pH}$ range of $6.5-7.5$. During the initial stages of fermentation, $\mathrm{pH}$ will likely drop below 6 or lower. However, after $2-3$ weeks, the $\mathrm{pH}$ will return up with the growth of methanogenic bacteria. The rate of decrease or increase in $\mathrm{pH}$ that is too extreme usually tends to cause the microbial population, especially bacteria to come down so that the digestive process of anaerobic is interrupted. The value of $\mathrm{pH}$ range generated in the POME degradation process with the help of a consortium bacteria can be seen in Fig. 6. The measurement of $\mathrm{pH}$ value is used $\mathrm{pH}$ meter digital.

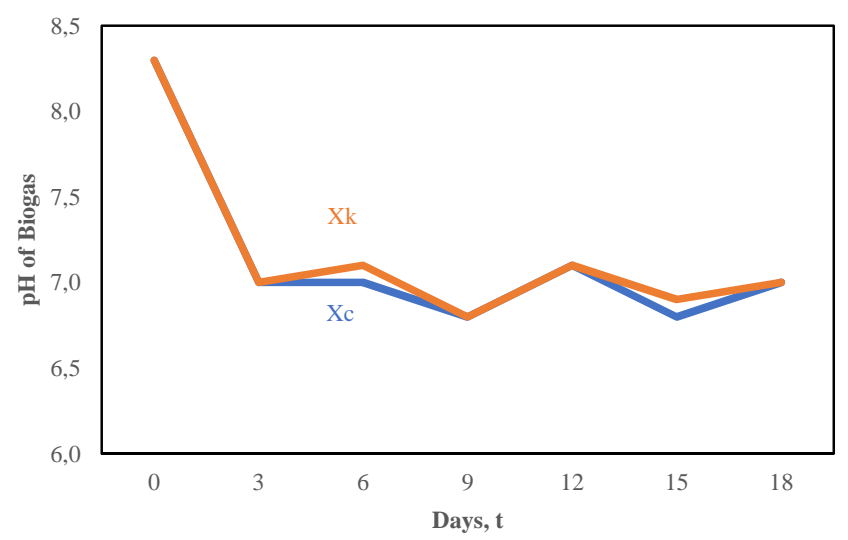

Fig. 6 Analysis $\mathrm{pH}$ from biogas production

$\mathrm{pH}$ is a major component that greatly affects the fermentation process and biogas production at the hydrolysis stage. The hydrolysis stage is the first protein breakdown process, to produce simple complex organic compounds such as amino acids. The $\mathrm{pH}$ of free or domestic waste is usually less than 7 . The use of $\mathrm{pH}$ under a neutral $\mathrm{pH}$ provides unclear results in the hydrolysis process. The results of the research influence the long-time anaerobic fermentation to $\mathrm{pH}$ can be seen in Fig. 6. The $\mathrm{pH}$ of the POME substrate on the first day of fermentation indicates a value of 8.3 from the consortium and KAN 1 bacterial. The decrease in $\mathrm{pH}$ value occurs as the fermentation time increases. The fermentation in day 3 to 15 , the $\mathrm{pH}$ value indicates the number 6.9-7.0. On the $18^{\text {th }}$ day, the $\mathrm{pH}$ value is 7.0 from consortium and KAN 1 bacterial. If $\mathrm{pH}$ has shown a value of 6.8 then it is assumed to contain methane bacteria which is a bacterium to produce methane gas. Factors that affect the value of $\mathrm{pH}$ due to nutrient content are increasingly reduced due to bacteria consumption.

\section{CONCLUSIONS}

The consortium bacteria produced from indigenous bacteria of KP 1.2 and KAN 1 was developed well within the substrate of POME. Biogas produced from the consortium bacteria is higher compared with biogas from the indigenous bacteria of KAN 1. The number of bacterial populations is $7.94 \times 10^{7} \mathrm{mg} / \mathrm{mL}$ and $7.23 \times 10^{7} \mathrm{mg} / \mathrm{mL}$ from the consortium and KAN 1 bacterial on the $35-38^{\text {th }}$ day. 
The number of bacteria that exist is perfectly degraded the substrate of POME, which can need enough time to produce a methane gas of $68.6 \%$ mole and a carbon dioxide gas of $21.7 \%$ mole for consortium bacteria on the $35-38^{\text {th }}$ day with the high degree of acidity $(\mathrm{pH})$ of 7.0. The KAN 1 bacteria can produce a methane gas of $64.0 \%$ mole and a carbon dioxide gas of $22.0 \%$ mole on the $35-38^{\text {th }}$ day with a high degree of acidity $(\mathrm{pH})$ of 7.0. Consortium bacterial can degrades lipid, protein and cellulose content in the POME while KAN 1 bacteria degrade the protein and cellulose content in the POME.

\section{ACKNOWLEDGMENT}

The authors thank the Chemical Engineering Department and Biology Laboratory of Sriwijaya University for the support of laboratory facilities during the research.

\section{REFERENCES}

[1] M. Habibullah and Sub-directorate of Estate Crops Statistics, Indonesian Oil Palm Statistics, Jakarta: BPS-Statistic Indonesia, 2017.

[2] P. N. Rahardja, "Comparative study about liquid waste processing technology of palm oil mill effluent," Environment Technology of Journal, vol. 10 (1), ISSN 1441-318X. 2009.

[3] A. S. Rahayu, D. Karsiwulan, H. Yuwono, I. Trisnawati, S. Mulyasari, S. Rahardjo, S. Hokermin, and V. Paramita, POME to Biogas $2^{\text {nd }}$ Edition. Jakarta: Winrock International, 2015.

[4] T. E. Agustina, B. Sulistyono, and R. Anugrah, "Treatment of palm oil mill effluent with Fenton and adsorption-Fenton combination methods," Chemical Engineering of Journal, vol. 22 (3). 2016.

[5] I. J. Ibe, J. N. Oblige, J. Orji, P. L. Nwanze, C. Ibejisika, and B. N. Okechi, "Effects of palm oil mill effluent (POME) on soil bacteria and enzymes at a different season," Int. J. Curr Microbial. App. Sci. vol. 3 (10), pp. 928-934, 2014.

[6] S. N. B. A. Khadaroo, P. Grassia, P. Gouwanda, and P. E. Poh, "Is the dewatering of palm oil mill effluent (POME) feasible? Effect of temperature on POME's rheological properties and compressive behavior," Chemical Engineering Science, vol. 202, pp. 519-528, 2019.

[7] W. L. Liew, M. A. Kassim, K. Muda, S. K. Loh, and A. C. Affam, "Conventional methods and emerging wastewater polishing technologies for palm oil mill effluent treatment: a review," Journal of Environmental Management, vol. 149, pp. 222-235, 2015.

[8] Z. S. Lee, S. Y. Chin, J. W. Lim, T. Witoon, and C. K. Cheng, "Treatment technologies of palm oil mill effluent (POME) and olive mill wastewater (OMW): a brief review," Environmental Technology \& Innovation, vol. 15, 2019.

[9] Y. Y. Choong, K. W. Chou, and I. Norli, "Strategies for improving biogas production of palm oil mill effluent (POME) anaerobic digestion: A critical review," Renewable and Sustainable Energy Reviews, vol. 82, pp. 2993-3006, 2018.

[10] S. N. B. A. Khadaroo, P. E. Poh, D. Gouwanda, and P. Grassia, "Applicability of various pretreatment techniques to enhance the anaerobic digestion of palm oil mill effluent (POME): a review," Journal of Environmental Chemical Engineering, vol. 7, 2019.

[11] S. Siddarth, "Green energy anaerobic digestion," Proceedings of the 4th WSEAS Int. Conf. on Heat Transfer, Thermal Engineering and
Environment, Elounda, Greece, Third Year Chemical Engineering, Sri Venkateswara College Of Engineering Sriperumbudur Anna University, 2006, pp. 276- 280.

[12] E. I. Ohimain and S. C. Izah, "A review of biogas production from palm oil mill effluents using different configurations of bioreactors," Renewable and Sustainable Energy Reviews, vol. 70, pp. 242-253, 2017.

[13] A. N. Garritano, M. O. Faber, L. R. V. De Sa, and V. S. F. Leitao, "Palm oil mill effluent (POME) as raw material for biohydrogen and methane production via dark fermentation," Renewable and Sustainable Energy Reviews, vol. 92, pp. 676-684, 2018.

[14] Sarono, O. Suparno, Suprihatin, and U. Hasanudin, "The performance of biogas production from POME at different temperatures," International Journal of Technology, vol. 8, pp. 14131421, 2016.

[15] H. Tijani, N. Abdullah, dan A. Yuzir, "Enhancing methane production of palm oil mill effluent using two-stage domesticated shear-loop anaerobic contact stabilization system," Journal of Cleaner Production, vol. 200, pp. 971-981, 2018.

[16] S. Saelor, P. Kongjan, and S. O-Thong, "Biogas production from anerobic co-digestion of palm oil mill effluent and empty fruit bunches," Energy Procedia, pp. 717-722, 2017.

[17] A. Z. Taifor, M. R. Zakaria, M. Z. M. Yusoff, M. Toshinari, M. A. Hassan, and Y. Shirai, "Elucidating substrate utilization in biohydrogen production from palm oil mill effluent by Escherichia coli," International Journal of Hydrogen Energy, vol. 42, pp. 58125819, 2017.

[18] S. Lanka and M. Pydipalli, "Reduction of organic load from palm oil mill effluent (POME) using selected fungal strains isolated from POME dump sites," African Journal of Biotechnology, vol. 17, pp. 1138-1145, 2018.

[19] M. Soleimaninanadegani and S. Manshad, "Enhancement of biodegradation of palm oil mill effluents by local isolated microorganism," International Scholarly Research Notice, pp. 1-8, 2014 ,

[20] D. Marin, E. Posadas, D. Garcia, D. Puyol, R. Lebrero, and R. Munoz, "Assessing the potential of purple phototrophic bacteria for the simultaneous treatment of piggery wastewater and upgrading of biogas," Bioresources Technology, vol. 281, pp. 10-17, 2019

[21] M. Aznury, Jaksen, A. Hasan, and A. P. Dila, "Production biomethane from palm oil mill effluent (POME) with truncated pyramid digester in fed batch system," Proceeding of the 6th International Conference of the Indonesian Chemical Society, 2018.

[22] S. Krishnan, M. F. M. Din, S. M. Taib, M. Nasrullah, M. Sakinah, Z. A. Wahid, H. Kamyab, S. Chelliapan, S. Rezania, and L. Singh, "Accelerated two-stage bioprocess for hydrogen and methane production from palm oil mill effluent using continuous stirred tank reactor and microbial electrolysis cell," Journal of Cleaner Production, vol. 229, pp. 84-93, 2019.

[23] N. I. H. A. Aziz and M. M. Hanafiah, "Life cycle analysis of biogas production from anaerobic digestion of palm oil mill effluent," Renewable Energy, vol. 145, pp. 847-857, 2019.

[24] B. S. Zainal, A. Akhbari, A. A. Zinatizadeh, P. Mohammadi, M. Danaee, N. S. Mohd, and S. Ibrahim, "UASFF start-up for biohydrogen and biomethane production from treatment of palm oil mill effluent," International Journal of Hydrogen Energy, vol. 44, pp. 20725-20737, 2018.

[25] V. Paolini, M. Torre, W. Giacopini, M. Pastori, M. Segreto, L. Tomasseetti, M. Carnevale, F. Galluci, F. Petracchini, and E. Guerriero, " $\mathrm{CO}_{2} / \mathrm{CH}_{4}$ separation by hot potassium carbonate absorption for biogas upgrading," International Journal of Greenhouse Gas Control, vol. 83, pp. 186-194, 2019. 